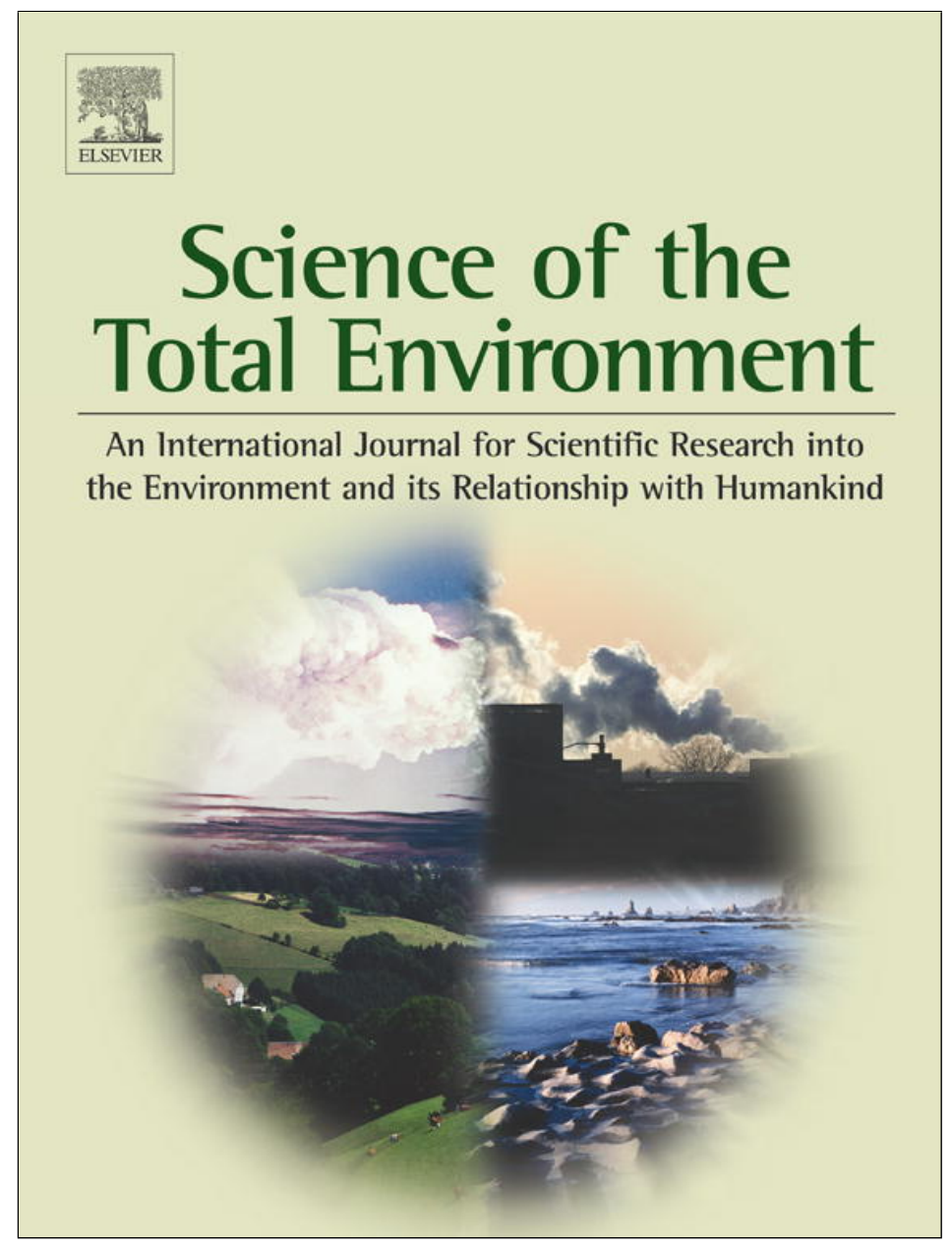

This article appeared in a journal published by Elsevier. The attached copy is furnished to the author for internal non-commercial research and education use, including for instruction at the authors institution and sharing with colleagues.

Other uses, including reproduction and distribution, or selling or licensing copies, or posting to personal, institutional or third party websites are prohibited.

In most cases authors are permitted to post their version of the article (e.g. in Word or Tex form) to their personal website or institutional repository. Authors requiring further information regarding Elsevier's archiving and manuscript policies are encouraged to visit: 


\title{
Constructed wetlands with light expanded clay aggregates for agricultural wastewater treatment
}

\author{
A. Dordio ${ }^{\mathrm{a}, \mathrm{b}, *}$, A.J.P. Carvalho ${ }^{\mathrm{a}, \mathrm{c}}$ \\ a Chemistry Department, University of Évora, Rua Romão Ramalho 59, 7000-676 Évora, Portugal \\ b IMAR - Marine and Environmental Research Centre, University of Évora, Rua Romão Ramalho 59, 7000-676 Évora, Portugal \\ c $C Q E$ - Évora Chemistry Centre, University of Évora, Rua Romão Ramalho 59, 7000-676 Évora, Portugal
}

\section{H I G H L I G H T S}

- CW with LECA substrate and Phragmites plants tested with agricultural wastewaters.

- High removals of TSS, COD, $\mathrm{NH}_{4}-\mathrm{N}$, polyphenols, a pharmaceutical and a pesticide.

- Contact time of wastewaters with beds ranged from 3 to 9days in batch conditions.

- Promising results suggest more studies in full-scale and more realistic conditions.

\section{A R T I C L E I N F O}

\section{Article history:}

Received 4 April 2013

Received in revised form 29 May 2013

Accepted 11 June 2013

Available online $\mathrm{xxxx}$

Associate Editor: D. Barcelo

\section{Keywords:}

LECA

Phragmites

Olive mill wastewater

Swine wastewater

Oxytetracycline

MCPA

\begin{abstract}
A B S T R A C T
Constructed wetlands (CWs) are receiving a renewed attention as a viable phytotechnology for treating agricultural wastewaters and for the removal of more specific pollutants, in particular recalcitrant ones. In this work, the performance of CW mesocosms using light expanded clay aggregates (LECA) as the bed's substrate and planted with Phragmites australis was investigated for treatment of olive mill wastewater (OMW), swine wastewater (SW) contaminated with oxytetracycline and water contaminated with herbicide MCPA (2-methyl-4-chlorophenoxyacetic acid). Both wastewaters (OMW and SW) initially presented high organic matter content and total suspended solids which were removed by the system with efficiencies higher than $80 \%$. Removal of polyphenols in OMW and nitrogen compounds in SW also showed similar or higher efficiencies in comparison with other treatment systems reported in the literature. The antibiotic oxytetracycline was completely removed from SW within the assay period in unplanted LECA beds, but planted beds allowed a significantly faster removal. In regard to water contaminated with MCPA, the results showed that LECA has a large sorption capacity for this herbicide (removal efficiencies of 56-97\%). In general, considerably higher pollutant removal efficiencies were obtained when plants were used (up to $28 \%$ higher). The results obtained are indicative that CWs with LECA as substrate may be an adequate option for agricultural wastewater treatment.
\end{abstract}

(C) 2013 Published by Elsevier B.V.

\section{Introduction}

Pollution resulting from agricultural activities can cause a significant deterioration of surface and groundwater quality. The most common pollutant types arising from it are high loads of oxygen-demanding organic compounds, associated nutrients (particularly nitrogen and phosphorus) and a variety of organic xenobiotic substances applied to cultures, soils or used in livestock, such as pesticides and pharmaceuticals. These pollutants may contaminate surface waters from point sources typically associated with concentrated farming activities or from diffuse or non-point sources associated with surface runoff

* Corresponding author at: Chemistry Department, University of Évora, Rua Romão Ramalho 59, 7000-676 Évora, Portugal. Tel.: + 351266745343.

E-mail address: avbd@uevora.pt (A. Dordio). (which may be potentially more problematic due to the difficulty to intercept and treat those pollution sources). Examples of insidiously challenging cases of agricultural pollution sources are the wastewaters resulting from the production of livestock such as piggeries, or food industries such as olive oil production, and situations of water contamination with pesticides after runoff events (Cronk, 1996; Fiorentino et al., 2003; Justino et al., 2012; Matamoros et al., 2012b).

Swine wastewaters (SW) contain highly concentrated pollutants, including suspended solids, organic matter, nutrients, pathogenic organisms and, frequently, also the presence of some pharmaceuticals such as oxytetracycline (OTC) (Cronk, 1996; Knight et al., 2000; Villamar et al., 2012; Chen et al., 2012; Cavenati et al., 2012).

In Mediterranean countries where olive tree culture is well established and available water resources are scarce, an important source of river contamination is olive mill wastewater (OMW) 
(Fiorentino et al., 2003; Justino et al., 2012). The environmental impact of OMW is mainly due to its high contents of organic matter, total suspended solids, a significant content of phytotoxic and antibacterial phenolic compounds, acidic pH, dark colour and unpleasant smell (Fiorentino et al., 2003; Greco et al., 2006; Azaizeh et al., 2012; Justino et al., 2012). Another characteristic of OMW (which is common to some other agricultural wastewaters such as those from wineries and sugarcane processing) is its seasonality, associated with the period of fruit harvesting.

Pesticides used in agriculture present a particularly important environmental threat due to their ecotoxicity which stems naturally from their purpose (Reichenberger et al., 2007; Buchanan et al., 2011). MCPA, a systemic herbicide used for the post-emergence control of broad-leaf weeds (Tomlin, 1994), is such an example of an agricultural pesticide that is commonly found in waters and soil (Silva et al., 2006; Köck et al., 2010; Botta et al., 2012; Matamoros et al., 2012a). The risks of leaching from soil into ground and surface water are significant, due to the relatively high water solubility (825 $\mathrm{mg} \mathrm{L}^{-1}$ ) and mobility, and a persistence in the environment of several weeks (Laganá et al., 2002; Cerejeira et al., 2003).

Evaporation ponds and/or, in some cases, anaerobic digestion are widely used to manage some types of agricultural wastewater such as OMW or SW. Land spreading is also practiced in some cases as a way to dispose sludges and simultaneously improve soil fertility. Evaporation ponds provide a low cost technology, but they have relatively high area requirements, especially in regions with low evaporation rates, and are associated with the development of odors and leakage of wastewater to surface or groundwater. Most of these solutions are low cost but they do not provide a comprehensive efficient treatment for all the important pollutants as they are generally targeted for bulk pollutants (for example, organic xenobiotics such as pesticides and pharmaceuticals are, in general, not efficiently removed by any of these more conventional approaches). For some types of wastewater (e.g. OMW) advanced technologies such as advanced oxidative processes have been proposed but these are characterized by high operational costs and frequently require complex maintenance and availability of experienced personnel (Justino et al., 2012).

In recent years, the use of constructed wetlands (CWs) for the treatment of agricultural wastewaters, including those produced by food-processing industries and by livestock farms, has been gaining popularity due to their relatively low construction costs and maintenance requirements (Cronk, 1996; Knight et al., 2000; Del Bubba et al., 2004; Carty et al., 2008; Harrington and McInnes, 2009; Yalcuk et al., 2010; Herouvim et al., 2011; Yalcuk, 2011; Harrington et al., 2012; Kapellakis et al., 2012; Justino et al., 2012). Their use as buffer zones to provide effective protection of water bodies from agricultural runoff events, namely for the containment of associated pesticide contamination hazards, has also been studied and applied (Gregoire et al., 2009; Warsaw et al., 2012; Matamoros et al., 2012b).

If the capacity of CWs to depurate waters from bulk pollutants and nutrients is generally recognized, recent research has been directed to the removal of other contaminants such as metals and organic micropollutants from several types of wastewaters (Matamoros et al., 2008; Rai, 2008; Imfeld et al., 2009; Park et al., 2009; Avila et al., 2010; Marchand et al., 2010; Breitholtz et al., 2012). In particular, several studies showed successful applications of CWs to remove hardly biodegradable organic xenobiotic compounds such as pesticides and pharmaceuticals (Cheng et al., 2002; Matamoros et al., 2008, 2012a; Dordio et al., 2009b, 2010; Avila et al., 2010; Hijosa-Valsero et al., 2011; Agudelo et al., 2012; Warsaw et al., 2012).

Optimization of CWs for removal of particular pollutants can be achieved by careful selection of its components, such as the plant species used and the materials which compose the support matrix. A suitable choice of the latter is especially important for the removal of non-biodegradable compounds (including phenolic compounds, pharmaceuticals and pesticides) where sorption processes can play the major role in the wastewater treatment (Reddy and DeLaune, 2008; Imfeld et al., 2009; Ahmad et al., 2010; Passeport et al., 2011). In previous studies, light expanded clay aggregate (LECA) materials have been proven adequate for the development of plants and microorganisms in CWs and showed a high capacity to sorb many types of organic molecules (Dordio et al., 2007, 2009a, 2010; Calheiros et al., 2008).

This study evaluates the efficiency of a LECA-based CW mesocosm planted with Phragmites australis to treat two different types of agricultural wastewaters, namely a swine wastewater and an olive mill wastewater, and an aqueous solution of a commonly used herbicide, MCPA. With this study, an assessment is made of the suitability and performance of this support matrix material for the treatment of agricultural wastewaters, not only for removal of high loads of suspended solids, organic matter and nutrients, as is achieved by other treatment systems (including other CWs systems, but using other types of support matrix materials such as the more commonly used gravel), but also for removing other more recalcitrant pollutants such as polyphenols and xenobiotics such as pesticides and pharmaceuticals.

\section{Materials and methods}

\subsection{Reagents and materials}

2-Methyl-4-chlorophenoxyacetic acid (MCPA) (97\% purity) was purchased from Sigma Aldrich (Steinheim, Germany). Oxytetracycline (OTC) (98\% purity) was purchased from Acrōs Organics (New Jersey, USA). All other high purity chemicals and solvents were purchased from Sigma-Aldrich (Steinheim, Germany), Merck (Darmstadt, Germany) or Panreac Quimica SA (Barcelona, Spain) and were used without further purification.

LiChrolut ${ }^{\circledR}$ RP-18 (500 mg, 3 mL) cartridges from Merck (Darmstadt, Germany) were used for solid phase extraction (SPE). Filters with $0.45 \mu \mathrm{m}$ nylon membrane were purchased from VWR International (West Chester, PA, USA).

Ultra-pure water was obtained with a Milli-Q water purification

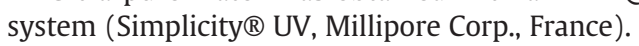

Gravel (grain sizes of 10-15 mm) and LECA (granulometric grades $2 / 4$ and $3 / 8$ ), which were used for the support matrix of the CWs mesocosms, were supplied by Brispedra (Portugal) and MaxitGroup (Portugal) respectively. Prior to use, gravel and LECA were washed several times with Millipore water in order to remove fine particles and suspended solids, and finally air dried. Physical and chemical characterization of this batch of LECA employed in the present assays was conducted in a previous study (Dordio et al., 2009a).

\subsection{Setup of mesocosm wetland assays}

\subsubsection{Assays with olive mill wastewater}

Four mesocosms were set up in plastic containers $\left(0.6 \mathrm{~m}^{2} \times\right.$ $0.53 \mathrm{~m}$ deep) filled with gravel and LECA. The support matrix was composed by a $10 \mathrm{~cm}$ bottom layer of gravel (grain sizes of $10-20 \mathrm{~mm}$ ), followed by a $25 \mathrm{~cm}$ layer of LECA $2 / 4$ and a $10 \mathrm{~cm}$ top layer of LECA $3 / 8$.

The beds were loaded to a constant flooding rate (defined as the percentage of the void volume of the bed, i.e. the total amount of water needed for complete inundation up to the surface, that is to be filled with liquid) of $75 \%$. Taking into account that the wastewater contained a high amount of suspended solids that should be removed in advance, the top dry layer of the bed thus served as a filtering medium enabling the separation (and mineralization) of the solid fraction of the wastewater when the bed was being loaded vertically. The remaining lower part of the bed was permanently flooded thereby allowing a longer contact with the solid media (especially the LECA material) for the occurrence of biodegradation of the soluble and colloidal organic matter and of sorption processes, which are 
the main removal processes in these systems (Kadlec and Wallace, 2009; Dordio and Carvalho, 2013).

Two beds were planted with pre-grown $P$. australis (density of 14 plants $/ \mathrm{m}^{2}$, average plant height of $35 \mathrm{~cm}$ ) and another two were left unplanted. The reeds were established through a three-month irrigation strategy prior to the application of effluent.

After this period, and during another three months, the beds were gradually acclimated to the wastewaters by consecutively feeding them with diluted wastewater solutions at progressively increasing concentrations up to the concentrations used in the assays. This procedure was intended to allow the gradual establishment of the system, especially the development of the microbial communities and the acclimation of the plants, and to mitigate toxicity problems. During this period it was noted that a pre-diluted OMW should be used in the assays instead of a raw concentrated one in order to reduce the phytotoxicity of the phenolic compounds and major clogging problems caused by high concentrations of suspended solids. In fact, in a real application, the OMW can be dosed in a CW at very little hydraulic loading rates and after dilution by taking advantage of the facts that OMW are produced in a short period of the year and there is a long elapsing time between two subsequent oil campaigns (Del Bubba et al., 2004).

\subsubsection{Assays with swine wastewater}

In the case of assays using swine wastewater, a setup similar to the one used in the OMW assays was employed. A significant amount of suspended solids is also present in SW and, thus, similar support matrix stratification and flooding rate were used as in the previous case. As in the case of the OMW assays, a pre-dilution of SW was also adopted to prevent clogging problems. The pre-diluted SW was spiked with pharmaceutical OTC at a concentration of $1 \mu \mathrm{g} \mathrm{mL}-1$.

\subsubsection{Assays with MCPA solutions}

Eight mesocosms were set up in plastic containers with dimensions identical to those used in the assays with other wastewaters as described above. The beds were filled with $10 \mathrm{~cm}$ of gravel (grain sizes of $10-20 \mathrm{~mm}$ ) as the bottom layer, followed by a $35 \mathrm{~cm}$ layer of LECA $2 / 4$ as the top layer. Since the MCPA solutions do not contain any significant amounts of solids, the finer grade of LECA could be used without any risk of clogging, with the advantage that LECA 2/4 has been already assessed to retain by sorption much higher amounts of MCPA than LECA 3/8 (Dordio et al., 2007). The flooding rate for these assays was around $100 \%$.

Four beds were planted with $P$. australis and another four were left unplanted, in identical conditions to the other assays described above. Two of the planted beds and two of the unplanted ones were fed with $1 \mu \mathrm{g} \mathrm{mL}{ }^{-1}$ MCPA solution, whereas the remaining two planted and two unplanted beds were fed with $5 \mu \mathrm{g} \mathrm{mL}{ }^{-1}$ MCPA solution.

\subsection{Operation of the mesocosm wetlands and sample collection}

All systems were operated in a batch mode, i.e. with a single initial load of the wastewater and without any running flow of the liquids during the assays. Different contact times of the wastewaters with the beds were tested by collecting samples of the liquid at 3 days (in all assays), 6 days (in OMW and MCPA assays) and 9 days (in SW assays) after the beginning of each assay. Samples were collected at half depth of the beds and at random points over the bed surface. After collection, all samples were kept refrigerated until the time of analysis, which was always carried out within $2 \mathrm{~h}$ from the time of collection.

The $\mathrm{pH}$ of the solutions was monitored during the assays. Evaporation (and also transpiration in planted beds) was additionally daily controlled and the lost water volumes were restored with distilled water. Effects due to rainfall were excluded from this study as all the systems were placed under covered facilities.

\subsection{Analytical methodology for wastewater characterization}

Total suspended solids (TSS), chemical oxygen demand (COD), nitrate nitrogen $\left(\mathrm{NO}_{3}-\mathrm{N}\right)$, ammonia nitrogen $\left(\mathrm{NH}_{4}-\mathrm{N}\right)$ and $\mathrm{pH}$ determinations were performed according to the APHA-AWWA-WPCF methods (Clescerl et al., 1998). Total polyphenols content was determined spectrophotometrically by Folin-Denis method with modifications by Duran et al. (1991) and expressed as mg of caffeic acid equivalent (CAE). Briefly, a mixture of $5 \mathrm{~mL}$ of the sample and $2.5 \mathrm{~mL}$ of the Folin-Denis reagent was diluted to $50 \mathrm{~mL}$ with distilled water. After $3 \mathrm{~min}, 5 \mathrm{~mL}$ of a $20 \%$ sodium carbonate solution was added to that mixture and after $1 \mathrm{~h}$ it was centrifuged (10 min at $5000 \mathrm{rpm})$. The supernatant was collected and the spectrophotometrical measurement was carried out at $725 \mathrm{~nm}$.

OTC quantification in filtered liquid samples was performed by HPLC with UV detection at $356 \mathrm{~nm}$. The analytical column used was a reversed-phase Zorbax Eclipse XDB-C18 with $5 \mu \mathrm{m}$ particle sizes (Agilent Technologies, Germany) and the mobile phase was a mixture of acetonitrile:methanol:water with oxalic acid $10 \mathrm{mM}$ in isocratic mode. The flow rate was $1.0 \mathrm{~mL} \mathrm{~min}{ }^{-1}$ and the injection volume was $20 \mu \mathrm{L}$. Five replicate injections were made for each sample. The range of OTC concentrations used to construct the calibration curve spanned from 0.25 to $5.0 \mu \mathrm{g} \mathrm{mL}^{-1}$. In this concentration range a linear behavior is observed $\left(\mathrm{R}^{2}=0.999\right)$. For this analytical methodology the limit of detection (LOD) was $61 \mathrm{ng} \mathrm{mL}^{-1}$ and the limit of quantification (LOQ) was $190 \mathrm{ng} \mathrm{mL}^{-1}$. Whenever concentrations of the analyte were below the LOQ of the instrumental determination, a pre-concentration step was performed consisting of a previously optimized SPE procedure ( $\mathrm{pH}$ of the sample adjusted to 2, elution with $5 \mathrm{~mL}$ of methanol, drying under vacuum and redissolution with $1 \mathrm{~mL}$ of acetonitrile:water $(1: 1, \mathrm{v} / \mathrm{v}))$. The LOQ of the entire analytical method (including SPE pre-concentration, with analyte recoveries of $94 \pm 2 \%$ ), calculated according to Vieno et al. (2006), was $2 \mathrm{ng} \mathrm{mL}^{-1}$.

MCPA quantification in liquid samples was performed on a Hitachi U-2000 spectrometer at $\lambda=228.6 \mathrm{~nm}$ after centrifugation and filtration. The range of MCPA concentrations used to construct the calibration curve spanned from $0.5 \mu \mathrm{g} \mathrm{mL}^{-1}$ to $7 \mu \mathrm{g} \mathrm{mL}^{-1}$. In this concentration range a linear behavior is observed $\left(R^{2}=0.999\right)$. For this analytical methodology the limit of detection (LOD) was $0.08 \mu \mathrm{g} \mathrm{mL} \mathrm{L}^{-1}$ and the limit of quantification (LOQ) was $0.27 \mu \mathrm{g} \mathrm{mL}{ }^{-1}$. Whenever concentrations of the analyte were below the LOQ of the instrumental determination, a pre-concentration step was performed consisting of a previously optimized SPE procedure ( $\mathrm{pH}$ of the sample adjusted to 7, elution with $5 \mathrm{~mL}$ of methanol, drying under vacuum and redissolution with $1 \mathrm{~mL}$ of water). The LOQ of the entire analytical method (including SPE pre-concentration, with analyte recoveries of $97 \pm 2 \%$ ), calculated according to Vieno et al. (2006), was $5.6 \mathrm{ng} \mathrm{mL}^{-1}$.

\section{Results and discussion}

\subsection{Characterization of the conditions for the realization of the assays}

The chemical composition of OMW depends on the olive oil extraction process used (traditional pressing system or continuous three phase process), on the olive varieties and on climatic and soil conditions. In fact, chemical and physical properties change not only from year to year but also during the working period. The OMW used in this study, produced during the period from October to January, presented high concentrations of organic matter $(45.6 \pm 12 \mathrm{~kg}$ COD $\left.\mathrm{m}^{-3}\right)$, total suspended solids $\left(13.1 \pm 5 \mathrm{~kg} \mathrm{~m}^{-3}\right)$, polyphenols $\left(1.1 \pm 0.2 \mathrm{~kg} \mathrm{~m}^{-3}\right)$ and low $\mathrm{pH}(4.8 \pm 0.3)$.

The SW used in this study also contained high concentrations of organic matter $\left(11.4 \pm 2 \mathrm{~kg} \mathrm{COD} \mathrm{m}^{-3}\right)$, total suspended solids ( $4.1 \pm$ $\left.1 \mathrm{~kg} \mathrm{~m}^{-3}\right)$, nitrogen compounds $\left(\mathrm{NO}_{3}-\mathrm{N}=0.19 \pm 0.05 \mathrm{~kg} \mathrm{~m}^{-3}\right.$, $\left.\mathrm{NH}_{4}-\mathrm{N}=2.9 \pm 0.3 \mathrm{~kg} \mathrm{~m}^{-3}\right)$ and slightly basic $\mathrm{pH}(7.8 \pm 0.2)$. 
As already mentioned, these wastewaters were diluted before use in the assays and their average compositions after the pre-dilution are presented in Table 1.

\subsection{Organic matter and suspended solids removal efficiency}

The removal efficiencies of organic matter and suspended solids from OMW and SW by LECA beds, unplanted or planted with Phragmites, are presented in Table 2.

As can be seen, all beds removed reasonably high amounts of suspended solids and organic matter from both types of wastewater (with significantly higher efficiencies in the case of the OMW than in SW, despite the higher initial loads of the former wastewater), and the treatment efficiencies obtained both in the unplanted and the planted beds were comparable to those obtained in other CW systems for similar contact times (Table 3 ). In regard to the comparisons with other studies, however, it should be noted that many of the cited examples refer to systems operated in continuous flow regimes and, therefore, the differences to a batch assay, as is the case of this study, should be weighted in that comparison. In the present assays, both TSS and COD values have rapidly diminished within the first sampling period (after $3 \mathrm{~d}$ of contact time) which can be interpreted as an indication that the removal of most organic matter $(>60 \%)$ is associated with the retention of solids of both wastewaters (SW and OMW) by the beds. This rapid removal of solids has shown the effectiveness of LECA as filter material and the adequacy of the materials stratification adopted in the beds' design which should substantially limit clogging problems. After $3 \mathrm{~d}$ there was still some increase in the removal efficiency of both TSS (5-14\%) and organic matter (8-16\%). Not much difference could be observed in the removal of TSS between planted and unplanted beds, given that most filtration is accomplished at the top layer of smaller grains of LECA. On the other hand, planted systems were significantly more efficient in the removal of organic matter than the unplanted LECA beds. In particular in the case of SW, a reasonably high increase in removal efficiency could still be observed after $3 \mathrm{~d}$ in planted beds. However, in the comparison with OMW assays it should be noted that the SW was allowed a longer contact time ( $9 \mathrm{~d}$ ) than the shorter $6 \mathrm{~d}$ period of the OMW case, thus allowing more extent for the slowest biodegradation processes. In addition, OMW is composed by a significant fraction of hardly biodegradable and toxic polyphenolic compounds that hinder the efficiency of biotic treatment processes.

\subsection{Nitrogen compounds removal efficiency}

The SW used in the assays contained a high concentration of nitrogen compounds, as is typical of this type of wastewater. The main removal/transformation processes for nitrogen compounds in CWs include plant uptake of the $\mathrm{NH}_{4}-\mathrm{N}$ and/or $\mathrm{NO}_{3}-\mathrm{N}$ forms (but to an extent that is generally considered to be low (Vymazal, 2007)), microbial degradation (ammonification, nitrification and denitrification), microbial assimilation, sorption/ion-exchange at the bed's substrate and, in free water surface CWs (but not on subsurface systems such as the ones in this study), also volatilization of ammonia. In fact, excluding the

Table 1

Average composition of the pre-diluted influents (mean \pm SD).

\begin{tabular}{lll}
\hline Parameters & OMW $^{\mathrm{a}}$ & $\mathrm{SW}^{\mathrm{a}}$ \\
\hline $\mathrm{pH}$ & $6.6 \pm 0.1$ & $7.9 \pm 0.1$ \\
$\mathrm{COD}\left(\mathrm{mg} \mathrm{L}^{-1}\right)$ & $2160 \pm 98$ & $1420 \pm 71$ \\
$\mathrm{TSS}\left(\mathrm{mg} \mathrm{L}^{-1}\right)$ & $616 \pm 34$ & $480 \pm 30$ \\
$\mathrm{NH}_{4}-\mathrm{N}\left(\mathrm{mg} \mathrm{L}^{-1}\right)$ & n.d. & $392 \pm 20$ \\
$\mathrm{NO}_{3}-\mathrm{N}\left(\mathrm{mg} \mathrm{L}^{-1}\right)$ & n.d. & $24 \pm 2$ \\
Polyphenols $\left(\mathrm{mg} \mathrm{L}^{-1}\right)$ & $52.5 \pm 3.0$ & n.d. \\
\hline
\end{tabular}

\footnotetext{
${ }^{\text {a }}$ n.d. $=$ not determined.
}

conversions between different nitrogen forms, only ammonia volatilization, denitrification, plant uptake and ammonia sorption contribute to an actual removal of nitrogen from the wastewaters. Sorption and ion exchange processes are only significant for the removal of ammonia if the support matrix features suitable sorptive characteristics. Such is not the case for some of the most common types of substrates (e.g. gravel and sand) but it has been pointed out that clay materials and clayey soils can be effective in ammonia sorption (Vymazal, 2007).

As can be seen from the efficiency values displayed in Table 4, removal of $\mathrm{NH}_{4}-\mathrm{N}$ and $\mathrm{NO}_{3}-\mathrm{N}$ compounds present in $\mathrm{SW}$ by planted and unplanted LECA beds was only moderate, with the exception of the removal of $\mathrm{NH}_{4}-\mathrm{N}$ in planted beds which, after a period of $9 \mathrm{~d}$, eventually reached reasonably higher values. Comparisons with other studies are difficult to establish as the complex effects of inter-conversions between different $\mathrm{N}$ forms lead to very disparate values for not so different systems, showing a significant sensitivity of $\mathrm{N}$ removal efficiencies to the conditions of the assays. In the present study, improvements in the removal efficiencies could be observed for the planted systems, which were especially significant in the case of $\mathrm{NH}_{4}-\mathrm{N}$ removal which may be attributed to uptake of some $\mathrm{NH}_{4}-\mathrm{N}$ by plants and to the occurrence of nitrification phenomena. Removal of $\mathrm{NO}_{3}-\mathrm{N}$ was meaningful only for a contact time of up to $9 \mathrm{~d}$. Oxygen requirements of nitrification may be an obstacle to the effectiveness of this process, especially where beds are operated in a batch mode (as was the case with these assays) with a consequently poorer aeration due to the absence of liquid flow. However, macrophyte plants may balance the aeration needs as they provide an aerobic environment in the rhizosphere due to the oxygen release through their root system. In addition, the LECA material provides a suitable support matrix for the good development of nitrification bacteria development (Lekang and Kleppe, 2000) and, thus, these two components combined may have contributed to a significant $\mathrm{NH}_{4}-\mathrm{N}$ removal in the longer term.

The several possible inter-conversions between $\mathrm{N}$-forms occurring during the coupling of ammonification/nitrification/denitrification processes lead to variations in $\mathrm{NH}_{4}-\mathrm{N}$ and $\mathrm{NO}_{3}-\mathrm{N}$ concentrations that are difficult to interpret and which may mask the real effect of specific N-removal processes. In fact, because the process of nitrification of $\mathrm{NH}_{4}-\mathrm{N}$ leads to the formation of $\mathrm{NO}_{3}-\mathrm{N}$, the elimination of $\mathrm{NH}_{4}-\mathrm{N}$ may have been an important cause for the lower removal of $\mathrm{NO}_{3}-\mathrm{N}$ observed until $3 \mathrm{~d}$ of treatment. In addition, ammonification of organic nitrogen compounds may be a source of $\mathrm{NH}_{4}-\mathrm{N}$ and the effective removal of $\mathrm{NH}_{4}-\mathrm{N}$ by the system may have been much higher than the final $\mathrm{NH}_{4}-\mathrm{N}$ concentrations suggest.

\subsection{Polyphenols removal efficiency}

Polyphenols, which represent a significant part of the organic fraction of OMW, are typically one of the most toxic components of this kind of wastewater. In addition to its toxicity towards microorganisms and plants, the high concentrations in OMW result in its biodegradability being somewhat low (Herouvim et al., 2011; Yalcuk, 2011; Justino et al., 2012).

Efficiencies of OWM polyphenol removal by the studied treatment systems are shown in Table 5. These efficiency values for the planted beds were mostly at comparable levels of phenolic compound removal attained by other CWs as reported in several studies (Table 3), although we should again underline the fact that many of the examples given correspond to systems operated in continuous flow. Most polyphenols were removed in the initial period of treatment up to $3 \mathrm{~d}$, which is an indication that physical-chemical processes were essentially involved in polyphenols removal in this period, namely its removal associated with the retention of TSS and adsorption phenomena. Between $3 \mathrm{~d}$ and $6 \mathrm{~d}$ of contact time, an additional increase in removal efficiency could be associated with slower biodegradation processes. There is an overall benefit provided by the presence of plants in planted LECA beds as these systems exhibited 
Table 2

Removal efficiencies of organic matter (COD) and suspended solids (TSS) by LECA beds, unplanted or planted with Phragmites (mean \pm SD).

\begin{tabular}{|c|c|c|c|c|c|c|c|c|}
\hline \multirow[b]{3}{*}{ Contact time (d) } & \multicolumn{4}{|l|}{ OMW } & \multicolumn{4}{|l|}{ SW } \\
\hline & \multicolumn{2}{|c|}{ Unplanted beds } & \multicolumn{2}{|c|}{ Planted beds } & \multicolumn{2}{|c|}{ Unplanted beds } & \multicolumn{2}{|c|}{ Planted beds } \\
\hline & 3 & 6 & 3 & 6 & 3 & 9 & 3 & 9 \\
\hline COD removal (\%) & $71.6 \pm 3.0$ & $80.7 \pm 3.7$ & $84.1 \pm 2.9$ & $92.5 \pm 4.1$ & $60.0 \pm 3.2$ & $68.5 \pm 3.9$ & $64.5 \pm 3.8$ & $80.3 \pm 4.4$ \\
\hline TSS removal (\%) & $90.4 \pm 2.1$ & $95.3 \pm 2.2$ & $88.7 \pm 1.9$ & $94.7 \pm 1.7$ & $74.5 \pm 1.8$ & $86.3 \pm 2.2$ & $71.5 \pm 2.4$ & $85.8 \pm 2.0$ \\
\hline
\end{tabular}

a significant increase of about $15 \%$ in the polyphenol removal efficiencies and planted beds already showed a higher efficiency after only $3 \mathrm{~d}$ than unplanted beds attained after $6 \mathrm{~d}$.

Other studies had already pointed to better performances obtained with planted systems in comparison with unplanted ones and to the important role attributed to the micro-aerobic zones produced in the rhyzosphere (Yalcuk, 2011) as well as adsorption to the roots and phenol uptake by the plants (Tee et al., 2009; Graber et al., 2009).

\subsection{OTC removal efficiency}

OTC is a broad-spectrum antibiotic of the tetracycline family which is widely used in veterinary medicine (De Liguoro et al., 2003; Mahedero et al., 2005; Ja et al., 2008). This pharmaceutical is not efficiently removed by conventional wastewater treatments which results in its frequent detection in treated wastewaters and in water bodies of agricultural regions (Tong et al., 2009; Chen et al., 2012; Cavenati et al., 2012). Studies have shown that under a broad range of environmental conditions, tetracyclines can adsorb strongly to clays (Allaire et al., 2006; Avisar et al., 2010) which may be a good indication that a clay material-based CW, such as the present one with LECA support matrix, may provide efficient sorption mechanisms that can attain an efficient treatment of wastewaters contaminated with OTC

The performance of LECA alone in the removal of OTC through sorption was tested with SW spiked with $1 \mu \mathrm{g} \mathrm{mL} L^{-1}$ of OTC in the unplanted beds (Table 6). As can be seen, very high removal efficiencies were obtained within the shortest period of $3 \mathrm{~d}$ of wastewater contact with the beds, and virtually all OTC had been removed by the end of the assay after $9 \mathrm{~d}$ of contact. An important contribution of plants could be observed, with a faster removal obtained in the planted LECA beds in comparison with the unplanted beds (Table 6 ) and, after $3 \mathrm{~d}$, a nearly complete removal of OTC ( $>97 \%$ of the initial spiked amounts) attained

Table 3

Removal efficiencies of the studied agricultural pollutants obtained in other CWS, as reported in the available literature.

\begin{tabular}{|c|c|c|c|c|c|c|c|}
\hline $\begin{array}{l}\text { Wastewater } \\
\text { type }\end{array}$ & CW type & $\begin{array}{l}\text { Bed substrate } \\
\text { type }\end{array}$ & Plant type & HRT (d) & $\begin{array}{l}\text { Pollutant } \\
\text { type }\end{array}$ & Removal (\%) & References \\
\hline OMW & HSSF (pilot scale) & n.d. & Phragmites australis & 3 & $\begin{array}{l}\text { COD } \\
\text { TSS } \\
\text { Polyphenols }\end{array}$ & $\begin{array}{l}74.1 \pm 17.6 \\
73.9 \pm 14.9 \\
83.4 \pm 17.8\end{array}$ & Del Bubba et al. (2004) \\
\hline OPL & VSSF & Gravel & Phragmites australis & 3 & COD & 86 & Grafias et al. (2010) \\
\hline OMW & VSSF (pilot scale) & $\begin{array}{l}\text { Sand, zeolites } \\
\text { and gravel }\end{array}$ & $\begin{array}{l}\text { Typha latifolia }(\mathrm{T}) \text {, } \\
\text { Cyperus }(\mathrm{C})\end{array}$ & 3 & COD & $\begin{array}{l}73.5 \pm 16.1(T) \\
73.9 \pm 19.2(\mathrm{C}) \\
71.4 \pm 20.7(\mathrm{UP})\end{array}$ & Yalcuk et al. (2010) \\
\hline OMW & VSSF & $\begin{array}{l}\text { Sand, zeolites } \\
\text { and gravel }\end{array}$ & Cyperus & 3 & Phenol & $\begin{array}{l}74.5 \pm 14.2-89.7 \pm 2.6(\mathrm{P}) \\
73.4 \pm 19.1-83.2 \pm 5.1(\mathrm{UP})\end{array}$ & Yalcuk (2011) \\
\hline OMW & VSSF (pilot scale) & $\begin{array}{l}\text { Cobbles, gravel } \\
\text { and sand }\end{array}$ & Phragmites australis & 5 & $\begin{array}{l}\text { COD } \\
\text { Phenols }\end{array}$ & $\begin{array}{l}73 \\
75\end{array}$ & Herouvim et al. (2011) \\
\hline OMW & FWS (pilot scale) & Coarse and gravel & Phragmites australis & $5(\mathrm{TRT})$ & $\begin{array}{l}\text { COD } \\
\text { TSS } \\
\text { Phenols }\end{array}$ & $\begin{array}{l}80 \\
83 \\
74\end{array}$ & Kapellakis et al. (2012) \\
\hline SW & * & * & * & & $\begin{array}{l}\text { COD } \\
\text { TSS }\end{array}$ & $\begin{array}{l}47 \\
52\end{array}$ & Knight et al. (2000) \\
\hline SW & VSSF & n.d. & Cyperus flabelliformis & & COD & 95 & $\begin{array}{l}\text { Kantawanichkul et al. } \\
\text { (2001) }\end{array}$ \\
\hline SW & VSSF (lab scale) & gravel and sand & Phragmites australis & & $\begin{array}{l}\mathrm{TSS} \\
\mathrm{NH}_{4}-\mathrm{N}\end{array}$ & $\begin{array}{l}56.8 \\
27\end{array}$ & Sun et al. (2005) \\
\hline SW & HSSF & Sand and gravel & $\begin{array}{l}\text { Typha latifolia }(\mathrm{T}), \\
\text { Eleocharis interstincta }(\mathrm{E})\end{array}$ & 3 & TSS & $\begin{array}{l}67-78(\mathrm{~T}) \\
65-68(\mathrm{E}) \\
52-67(\mathrm{UP}) \\
75-78(\mathrm{~T}) \\
72-75(\mathrm{E}) \\
64-76(\mathrm{UP})\end{array}$ & Gonzalez et al. (2009) \\
\hline SW & VSSF & Pea gravel & Cyperus sp. & 3 & $\begin{array}{l}\mathrm{COD} \\
\mathrm{TSS} \\
\mathrm{NO}_{3}-\mathrm{N}\end{array}$ & $\begin{array}{l}67.7 \pm 1.7 \text { (P) } \\
66.1 \pm 1.7 \text { (UP) } \\
82.1 \pm 3.0 \text { (P) } \\
81.6 \pm 3.2 \text { (UP) } \\
49.0 \pm 6.3 \text { (P) } \\
50.4 \pm 5.1 \text { (UP) }\end{array}$ & Sarmento et al. (2012) \\
\hline $\begin{array}{l}\text { Artificial } \\
\text { wastewater }\end{array}$ & $\begin{array}{l}\text { VSSF and reverse } \\
\text { VSSF }\end{array}$ & Sand & $\begin{array}{l}\text { C. esculenta L. Schott and } \\
\text { I. aristatum van glaucum Honda }\end{array}$ & n.d. & MCPA & 36 & Cheng et al. (2002) \\
\hline Urban wastewater & WFS & - & $\begin{array}{l}\text { Phragmites } \\
\text { Typha }\end{array}$ & $\sim 30$ & MCPA & $79 \pm 2-93 \pm 1$ & Matamoros et al. (2008) \\
\hline
\end{tabular}

OMW: olive mill wastewater; OPL: olive pomace leachate; SW: swine wastewater.

HSSF: horizontal subsurface flow; VSSF: vertical subsurface flow; FWS: free water surface.

n.d: not detailed.

HRT: hydraulic retention time; TRT: theoretical retention time.

COD: chemical oxygen demand; TSS: total suspended solids: $\mathrm{NH}_{4}-\mathrm{N}$ : ammonia nitrogen; $\mathrm{NO}_{3}-\mathrm{N}$ : nitrate nitrogen.

P: planted; UP: unplanted. 
Table 4

Removal efficiencies of nitrogen compounds (in $\mathrm{NH}_{4}-\mathrm{N}$ and $\mathrm{NO}_{3}-\mathrm{N}$ forms) from SW by LECA beds, unplanted or planted with Phragmites (mean \pm SD).

\begin{tabular}{lllll}
\hline & \multicolumn{2}{l}{ Unplanted beds } & \multicolumn{2}{l}{ Planted beds } \\
\hline Contact time (d) & 3 & 9 & 3 & 9 \\
$\mathrm{NH}_{4}-\mathrm{N}$ removal (\%) & $35.3 \pm 3.7$ & $47.4 \pm 4.2$ & $54.1 \pm 3.9$ & $75.2 \pm 4.8$ \\
$\mathrm{NO}_{3}-\mathrm{N}$ removal (\%) & $12.1 \pm 3.1$ & $52.3 \pm 3.2$ & $19.9 \pm 2.9$ & $58.4 \pm 2.7$ \\
\hline
\end{tabular}

Table 5

Removal efficiencies of polyphenols from OMW by LECA beds, unplanted or planted with Phragmites (mean \pm SD)

\begin{tabular}{lllll}
\hline & \multicolumn{2}{l}{ Unplanted beds } & \multicolumn{2}{l}{ Planted beds } \\
\hline Contact time (d) & 3 & 6 & 3 & 6 \\
Polyphenols removal (\%) & $57.7 \pm 2.5$ & $64.1 \pm 2.9$ & $71.2 \pm 4.3$ & $80.3 \pm 5.2$ \\
\hline
\end{tabular}

by the planted systems. After $9 \mathrm{~d}$ of contact time no OTC could be detected in liquid.

\subsection{MCPA removal efficiency}

Previous studies have demonstrated that LECA exhibits a high sorption capacity for some organic pollutants including MCPA (Dordio et al., 2007, 2009a, 2009b; Calheiros et al., 2008). Sorption processes may be of major importance to achieve an efficient treatment of wastewaters, in particular in the case of hardly biodegradable organics, in which case the materials composing the support matrix may have a very relevant role.

The efficiency of LECA in removing MCPA through sorption was evaluated through assays performed in the unplanted beds (Table 7). These results are, to some extent, consistent with laboratory results reported earlier (Dordio et al., 2007), although some small loss of efficiency observed in the present study may be attributed to the longer age of operation of the beds and the establishment of biofilm on the LECA medium.

An enhanced efficiency was achieved by the planted LECA beds in comparison with the unplanted beds (Table 7). Even though most MCPA was retained at the LECA matrix, the presence of Phragmites plants contributed to a significantly faster removal process and after $3 \mathrm{~d}$ the planted systems had removed in addition to $26.2 \%-36.9 \%$ of the initial MCPA in comparison with the unplanted LECA beds. In the case of the $1 \mu \mathrm{g} \mathrm{mL}^{-1}$ MCPA solution, virtually all the herbicide had been already removed by the end of the assay, after $6 \mathrm{~d}$ of contact time. This contribution of plants is consistent with the effects on removal of other xenobiotics by other species in LECA beds (Dordio et al., 2009b, 2010). In addition to other more basic roles of plants in CW operation (Brix, 1997; Vymazal, 2011), these results demonstrate the potential for an equally important and active role played by the vegetation in the removal of specific organic pollutants such as MCPA, which enables the performance of planted systems to surpass that of a simpler LECA filter setup. Due to the moderate lipophilicity of MCPA, as expressed by its octanol-water partition coefficient (log $\mathrm{K}_{\mathrm{ow}}=1.37-1.43$ (Montgomery, 1993)), it is likely that plants have an active role in the removal of this compound through direct uptake. In fact, it is widely considered that organic compounds with $0.5<\log$ $\mathrm{K}_{\mathrm{ow}}<3$ have adequate properties to move through cell membranes

Table 6

Removal efficiencies of OTC from spiked SW (at initial concentrations of $1 \mu \mathrm{g} \mathrm{mL}^{-1}$ ) by LECA beds, unplanted or planted with Phragmites (mean \pm SD).

\begin{tabular}{cllll}
\hline & \multicolumn{2}{l}{ Unplanted beds } & \multicolumn{2}{l}{ Planted beds } \\
\hline Contact time (d) & 3 & 9 & 3 & 9 \\
OTC removal (\%) & $89 \pm 2.1$ & $99 \pm 1.6$ & $97 \pm 2.3$ & $100 \pm 1.8$ \\
$C_{\mathrm{i}=1 \mu \mathrm{gL}^{-1}}$ & & & & \\
\hline
\end{tabular}

Table 7

Removal efficiencies of MCPA from water (at initial concentrations of $1 \mu \mathrm{gL}^{-1}$ and $5 \mu \mathrm{gL}^{-1}$ ) by LECA beds, unplanted or planted with Phragmites (mean $\pm \mathrm{SD}$ ).

\begin{tabular}{lllll}
\hline \multicolumn{4}{l}{ Unplanted beds } & \multicolumn{3}{l}{ Planted beds } \\
\hline Contact time (d) & 3 & 6 & 3 & 6 \\
MCPA removal (\%) & $52.4 \pm 2.1$ & $96.7 \pm 3.3$ & $89.3 \pm 3.1$ & $99.1 \pm 3.6$ \\
$C_{\mathrm{i}}=1 \mu \mathrm{g} \mathrm{mL}^{-1}$ & & & & \\
$\mathrm{MCPA} \mathrm{removal} \mathrm{( \% )}$ & $40.0 \pm 2.4$ & $56.0 \pm 3.1$ & $66.2 \pm 3.6$ & $77.0 \pm 4.1$ \\
$\mathrm{C}_{\mathrm{i}}=5 \mu \mathrm{g} \mathrm{mL}^{-1}$ & & & & \\
\hline
\end{tabular}

and enter the plant's transpiration stream, thereby being easily taken up by the plants (Dietz and Schnoor, 2001; Pilon-Smits, 2005).

\subsection{Influence of LECA in wastewater $\mathrm{pH}$ within the beds}

The $\mathrm{pH}$ of the influent is an important parameter because it controls several biotic processes, besides having a major influence in the occurrence of some important physico-chemical processes within the CWs (e.g., plant and microorganism development is favored by a neutral environment and the extent to which ionizable compounds are removed is frequently dependent on their degree of ionization which in turn is determined by the solution $\mathrm{pH}$ ).

As LECA is a clay material, it contains many amphoteric constituents that can influence the $\mathrm{pH}$ of the wastewater within the beds (Dordio et al., 2007, 2009a). In order to assess the pH-control capabilities of LECA, non-diluted raw wastewaters (or aqueous solution of MCPA, $5 \mu \mathrm{g} \mathrm{mL}^{-1}$, initial $\mathrm{pH}=5.8$ ) were placed in contact with LECA and the value of $\mathrm{pH}$ was measured in liquid samples. Unplanted LECA beds were used in these tests due to the phytotoxicity of the raw wastewaters and in order to eliminate any interferences caused by plants, e.g. due to exudates released by roots.

It was observed that for the most acidic wastewater (OMW) the $\mathrm{pH}$ raised very quickly within the first 6 h to values close to 6 , and after 3 days the $\mathrm{pH}$ of all the wastewaters tended towards almost neutral values in the 7-8.5 range, independently of their initial values in any of the 3 different types of wastewater studied. This convergence of the $\mathrm{pH}$ values suggests that this material has some pH-buffering capacity which may be due to the presence of alkaline components in its composition, such as oxides and carbonates (e.g. traces of calcite) as has been determined in previous characterizations of the material (Dordio et al., 2007, 2009a). Its composition may, thus, yield a buffering power close to neutrality, thereby providing a protective barrier for plants and microorganisms.

\section{Conclusion}

A LECA-based CW planted with macrophytes $P$. australis has shown an overall high efficiency to remove several typical pollutants present in agricultural wastewaters, namely TSS and COD, nitrogen, polyphenols, a pharmaceutical and a pesticide (OTC and MCPA, respectively). Assays were performed in pre-diluted olive mill wastewater, pre-diluted swine wastewater spiked with OTC and an aqueous solution of the herbicide. For most pollutants considerably high removals were already attained after $3 \mathrm{~d}$ of treatment but, for significant efficiency of nitrogen removal (mainly in the ammonia form), a period of $9 \mathrm{~d}$ was required. The support matrix of LECA alone could be accounted as the major responsible for the efficiency of pollutant removal (especially TSS, organic matter and the pharmaceutical OTC; to a lesser but still significant extent, polyphenols and the pesticide MCPA), but the presence of vegetation in planted beds did contribute with an increased performance both in terms of efficiency as well as of the celerity of the process. Plants proved especially important to remove significant amounts of ammonia nitrogen, possibly due to the stimulation of nitrifying bacteria but also uptake of nitrogen compounds. LECA also showed the capacity to buffer the $\mathrm{pH}$ of both wastewaters to the range of neutrality or slight basicity, which contributes to its remarkable adequacy for the development of 
the plants and microorganisms. In comparison, this mesocosm CW showed efficiencies that have been on par with (or even higher than) other CWs for each of the tested pollutant types, but previous studies have never attempted to address (with success) such a wide range of different pollutant types with the same treatment system. Especially relevant was the fact that high removals of hardly biodegradable pollutants were also obtained with this CW (with this particular choice of plants and bed substrate) which, together with its low cost and ease of implementation and management, suggests this as a promising option for treatment of agricultural wastewaters. Nonetheless, further studies should be carried out with a wider range of wastewaters and pollutant types, in particular a larger variety of pesticides and veterinary pharmaceuticals. In addition, performances in full-scale systems and with other wastewater flow regimes should be assessed in order to confirm this solution as a viable option in the agricultural context.

\section{References}

Agudelo RM, Jaramillo ML, Penuela G. Comparison of the removal of chlorpyrifos and dissolved organic carbon in horizontal sub-surface and surface flow wetlands. Sci Total Environ 2012;431:271-7.

Ahmad T, Rafatullah M, Ghazali A, Sulaiman O, Hashim R, Ahmad A. Removal of pesticides from water and wastewater by different adsorbents: a review. J Environ Sci Health C Environ Carcinog Ecotoxicol Rev 2010;28:231-71.

Allaire SE, Del Castillo J, Juneau V. Sorption kinetics of chlortetracyline and tylosin on sandy loam and heavy clay soils. J Environ Qual 2006;35:969-72.

Avila C, Pedescoll A, Matamoros V, Bayona JM, Garcia J. Capacity of a horizontal subsurface flow constructed wetland system for the removal of emerging pollutants: an injection experiment. Chemosphere 2010;81:1137-42.

Avisar D, Primor O, Gozlan I, Mamane H. Sorption of sulfonamides and tetracyclines to montmorillonite clay. Water Air Soil Pollut 2010;209:439-50.

Azaizeh H, Halahlih F, Najami N, Brunner D, Faulstich M, Tafesh A. Antioxidant activity of phenolic fractions in olive mill wastewater. Food Chem 2012;134:2226-34.

Botta F, Fauchon N, Blanchoud H, Chevreuil M, Guery B. Phyt'Eaux Cités: application and validation of a programme to reduce surface water contamination with urban pesticides. Chemosphere 2012;86:166-76.

Breitholtz M, Naslund M, Strae D, Borg H, Grabic R, Fick J. An evaluation of free water surface wetlands as tertiary sewage water treatment of micro-pollutants. Ecotox Environ Safe 2012;78:63-71.

Brix H. Do macrophytes play a role in constructed treatment wetlands? Water Sci Technol 1997;35:11-7.

Buchanan I, Liang HC, Liu ZK, Razaviarani V. Pesticides and herbicides. Water Environ Res 2011;83:1549-97.

Calheiros CSC, Rangel AOSS, Castro PML. Evaluation of different substrates to support the growth of Typha latifolia in constructed wetlands treating tannery wastewater over long-term operation. Bioresour Technol 2008:99:6866-77.

Carty A, Scholz M, Heal K, Gouriveau F, Mustafa A. The universal design, operation and maintenance guidelines for farm constructed wetlands (FCW) in temperate climates. Bioresour Technol 2008;99:6780-92

Cavenati S, Carvalho PN, Almeida CM, Basto MC Vasconcelos MT. Simultaneous determination of several veterinary pharmaceuticals in effluents from urban, livestock and slaughterhouse wastewater treatment plants using a simple chromatographic method. Water Sci Technol 2012;66:603-11.

Cerejeira MJ, Viana P, Batista S, Pereira T, Silva E, Valério MJ, et al. Pesticides in Portuguese surface and ground waters. Water Res 2003;37:1055-63.

Chen Y, Zhang H, Luo Y, Song J. Occurrence and dissipation of veterinary antibiotics in two typical swine wastewater treatment systems in east China. Environ Monit Assess 2012;184:2205-17.

Cheng SP, Vidakovic-Cifrek Z, Grosse W, Karrenbrock F. Xenobiotics removal from polluted water by a multifunctional constructed wetland. Chemosphere 2002;48: $415-8$.

Clescerl LS, Greenberg AE, Eaton AD. Standard methods for the examination of wate and wastewater. Washington, D.C.: American Public Health Association; 1998

Cronk JK. Constructed wetlands to treat wastewater from dairy and swine operations: a review. Agric Ecosyst Environ 1996:58:97-114.

De Liguoro M, Cibin V, Capolongo F, Halling-Sorensen B, Montesissa C. Use of oxytetracycline and tylosin in intensive calf farming: evaluation of transfer to manure and soil. Chemosphere 2003;52:203-12

Del Bubba M, Checchini L, Pifferi C, Zanieri L, Lepri L. Olive mill wastewater treatment by a pilot-scale subsurface horizontal flow (SSF-h) constructed wetland. Ann Chim 2004;94:875-87.

Dietz AC, Schnoor JL. Advances in phytoremediation. Environ Health Perspect 2001;109:163-8.

Dordio AV, Carvalho AJP. Organic xenobiotics removal in constructed wetlands, with emphasis on the importance of the support matrix. J Hazard Mater 2013;252-253: 272-92.

Dordio AV, Teimao J, Ramalho I, Palace Carvalho AJ, Estevao Candeias AJ. Selection of a support matrix for the removal of some phenoxyacetic compounds in constructed wetlands systems. Sci Total Environ 2007:380:237-46.
Dordio AV, Candeias AJE, Pinto AP, da Costa CT, Carvalho AJP. Preliminary media screening for application in the removal of clofibric acid, carbamazepine and ibuprofen by SSF-constructed wetlands. Ecol Eng 2009a;35:290-302.

Dordio A, Pinto J, Pinto AP, da Costa CT, Carvalho A, Teixeira DM. Atenolol removal in microcosm constructed wetlands. Int J Environ Anal Chem 2009b;89:835-48.

Dordio A, Carvalho AJP, Teixeira DM, Dias CB, Pinto AP. Removal of pharmaceuticals in microcosm constructed wetlands using Typha spp. and LECA. Bioresour Technol 2010;101:886-92.

Duran RM, Padilla RB, Martin AM, De Ursinos JAFR, Mendoza JA. Biodegradation of phenolic-compounds present in oil-mill waste-water. Grasas Aceites 1991;42: 271-6.

Fiorentino A, Gentili A, Isidori M, Monaco P, Nardelli A, Parrella A, et al. Environmental effects caused by olive mill wastewaters: toxicity comparison of low-molecular-weigh phenol components. J Agric Food Chem 2003;51:1005-9.

Gonzalez FT, Vallejos GG, Silveira JH, Franco CQ Garcia J, Puigagut J. Treatment of swine wastewater with subsurface-flow constructed wetlands in Yucatan, Mexico: influence of plant species and contact time. Water SA 2009;35:335-42.

Graber A, Skvarc R, Junge-Berberovic R. Elimination of phenols, ammonia and cyanide in wash water from biomass gasification, and nitrogen recycling using planted trickling filters. Water Sci Technol 2009:60:3253-9.

Grafias P, Xekoukoulotakis NP, Mantzavinos D, Diamadopoulos E. Pilot treatment of olive pomace leachate by vertical-flow constructed wetland and electrochemical oxidation: an efficient hybrid process. Water Res 2010;44:2773-80.

Greco G, Colarieti ML, Toscano G, Iamarino G, Rao MA, Gianfreda L. Mitigation of olive mill wastewater toxicity. J Agric Food Chem 2006:54:6776-82.

Gregoire C, Elsaesser D, Huguenot D, Lange J, Lebeau T, Merli A, et al. Mitigation of agricultural nonpoint-source pesticide pollution in artificial wetland ecosystems. Environ Chem Lett 2009; 7:205-31.

Harrington R, McInnes R. Integrated constructed wetlands (ICW) for livestock wastewater management. Bioresour Technol 2009;100:5498-505.

Harrington C, Scholz M, Culleton N, Lawlor PG. The use of integrated constructed wetlands (ICW) for the treatment of separated swine wastewaters. Hydrobiologia 2012;692:111-9.

Herouvim E, Akratos CS, Tekerlekopoulou A, Vayenas DV. Treatment of olive mill wastewater in pilot-scale vertical flow constructed wetlands. Ecol Eng 2011;37: 931-9.

Hijosa-Valsero M, Matamoros V, Sidrach-Cardona R, Pedescoll A, Martin-Villacorta J, Garcia J, et al. Influence of design, physico-chemical and environmental parameters on pharmaceuticals and fragrances removal by constructed wetlands. Water Sci Technol 2011;63:2527-34.

Imfeld G, Braeckevelt M, Kuschk P, Richnow HH. Monitoring and assessing processes of organic chemicals removal in constructed wetlands. Chemosphere 2009;74:349-62.

Ja XF, Shao B, Wu YN, Yang Y, Zhang J. Simultaneous determination of tetracylines and quinolones antibiotics in egg by ultra-performance liquid chromatographyelectrospray tandem mass spectrometry. J AOAC Int 2008;91:461-8.

Justino C, Pereira R, Freitas A, Rocha-Santos T, Panteleitchouk T, Duarte A. Olive oil mill wastewaters before and after treatment: a critical review from the ecotoxicological point of view. Ecotoxicology 2012:21:615-29.

Kadlec RH, Wallace SD. Treatment wetlands. Boca Raton, FL: CRC Press; 2009.

Kantawanichkul S, Neamkam P, Shutes RBE. Nitrogen removal in a combined system: vertical vegetated bed over horizontal flow sand bed. Water Sci Technol 2001;44 $137-42$.

Kapellakis IE, Paranychianakis NV, Tsagarakis KP, Angelakis AN. Treatment of olive mill wastewater with constructed wetlands. Water 2012;4:260-71.

Knight RL, Payne VWE, Borer RE, Clarke RA, Pries JH. Constructed wetlands for livestock wastewater management. Ecol Eng 2000;15:41-55.

Köck M, Farré M, Martínez E, Gajda-Schrantz K, Ginebreda A, Navarro A, et al. Integrated ecotoxicological and chemical approach for the assessment of pesticide pollution in the Ebro River delta (Spain). J Hydrol 2010;383:73-82.

Laganá A, Bacaloni A, De Leva I, Faberi A, Fago G, Marino A. Occurrence and determination of herbicides and their major transformation products in environmental waters. Anal Chim Acta 2002;462:187-98.

Lekang OI, Kleppe H. Efficiency of nitrification in trickling filters using different filter media. Aquac Eng 2000;21:181-99.

Mahedero MC, Bohoyo D, Salinas F, Ardila T, Airado D, Roldan B. Improvements in europium sensitized fluorimetric determination of demeclocycline and methacycline. J Pharm Biomed Anal 2005;37:1101-4.

Marchand L, Mench M, Jacob DL, Otte ML. Metal and metalloid removal in constructed wetlands, with emphasis on the importance of plants and standardized measurements: a review. Environ Pollut 2010;158:3447-61.

Matamoros V, García J, Bayona JM. Organic micropollutant removal in a full-scale surface flow constructed wetland fed with secondary effluent. Water Res 2008:42:653-60.

Matamoros V, Arias CA, Nguyen LX, Salvadó V, Brix H. Occurrence and behavior of emerging contaminants in surface water and a restored wetland. Chemosphere 2012a;88:1083-9.

Matamoros V, Nguyen LX, Arias CA, Salvadó V, Brix H. Evaluation of aquatic plants for removing polar microcontaminants: a microcosm experiment. Chemosphere 2012b;88:1257-64.

Montgomery JH. Agrochemicals desk reference: environmental data. Chelsea, MI: Lewis Publishers; 1993.

Park N, Vanderford BJ, Snyder SA, Sarp S, Kim SD, Cho J. Effective controls of micropollutants included in wastewater effluent using constructed wetlands under anoxic condition. Ecol Eng 2009;35:418-23.

Passeport E, Benoit P, Bergheaud V, Coquet Y, Tournebize J. Selected pesticides adsorption and desorption in substrates from artificial wetland and forest buffer. Environ Toxicol Chem 2011;30:1669-76. 
Pilon-Smits E. Phytoremediation. Annu Rev Plant Biol 2005:56:15-39.

Rai PK. Heavy metal pollution in aquatic ecosystems and its phytoremediation using wetland plants: an ecosustainable approach. Int J Phytoremediation 2008;10: 133-60.

Reddy KR, DeLaune RD. Biogeochemistry of wetlands: science and applications. Boca Raton, FL: CRC Press; 2008.

Reichenberger S, Bach M, Skitschak A, Frede HG. Mitigation strategies to reduce pesticide inputs into ground- and surface water and their effectiveness; a review. Sci Total Environ 2007;384:1-35.

Sarmento AP, Borges AC, Matos AT. Evaluation of vertical-flow constructed wetlands for swine wastewater treatment. Water Air Soil Pollut 2012;223:1065-71.

Silva E, Batista S, Viana P, Antunes P, Serôdio L, Cardoso AT, et al. Pesticides and nitrates in groundwater from oriziculture areas of the 'Baixo Sado' region (Portugal). Int J Environ Anal Chem 2006;86:955-72.

Sun GZ, Zhao YQ Allen S. Enhanced removal of organic matter and ammoniacalnitrogen in a column experiment of tidal flow constructed wetland system. J Biotechnol 2005;115:189-97.

Tee HC, Seng CE, Noor AM, Lim PE. Performance comparison of constructed wetlands with gravel- and rice husk-based media for phenol and nitrogen removal. Sci Total Environ 2009;407:3563-71.

Tomlin C. The pesticide manual. Farnham, Surrey: British Crop Protection Council; 1994.
Tong L, Li P, Wang Y, Zhu K. Analysis of veterinary antibiotic residues in swine wastewater and environmental water samples using optimized SPE-LC/MS/MS. Chemosphere 2009;74:1090-7.

Vieno NM, Tuhkanen T, Kronberg L. Analysis of neutral and basic pharmaceuticals in sewage treatment plants and in recipient rivers using solid phase extraction and liquid chromatography-tandem mass spectrometry detection. J Chromatogr A 2006;1134: 101-11.

Villamar CA, Canuta T, Belmonte M, Vidal G. Characterization of swine wastewater by toxicity identification evaluation methodology (TIE). Water Air Soil Pollut 2012;223:363-9.

Vymazal J. Removal of nutrients in various types of constructed wetlands. Sci Total Environ 2007;380:48-65.

Vymazal J. Plants used in constructed wetlands with horizontal subsurface flow: a review. Hydrobiologia 2011;674:133-56.

Warsaw AL, Fernandez RT, Kort DR, Cregg BM, Rowe B, Vandervoort C. Remediation of metalaxyl, trifluralin, and nitrate from nursery runoff using container-grown woody ornamentals and phytoremediation areas. Ecol Eng 2012;47:254-63.

Yalcuk A. Removal of phenol from olive mill wastewater in constructed wetlands using different bedding media. Ekoloji 2011;20:1-5.

Yalcuk A, Pakdil NB, Turan SY. Performance evaluation on the treatment of olive mill waste water in vertical subsurface flow constructed wetlands. Desalination 2010;262: 209-14. 